10IKC-351

\title{
THE ORIGIN AND MODIFICATION OF THE SUB CONTINENTAL LITHOSPHERIC MANTLE OF BOTSWANA: CONSTRAINTS FROM PERIDOTITE XENOLITHS OF THE ORAPA MINE
}

\author{
Meulemans T.J. ${ }^{1}$, Borst A.M. ${ }^{1}$, Davidheiser B $^{2}$, Davies G.R. ${ }^{* 1}$ \\ ${ }^{1}$ Faculty of Earth and Life Sciences, VU University Amsterdam, De Boelelaan 1085, 1081 HV Amsterdam, \\ The Netherlands; ${ }^{2}$ University of Glasgow, SUERC, Rankine Avenue, East Kilbride, Glasgow G75 OQF, \\ United Kingdom*corresponding author: gareth.davies@falw.vu.nl
}

\section{INTRODUCTION}

Although Botswana is one of the most productive diamond producing countries little is known about the underlying mantle that formed the diamonds. Here we report on part of a series of ongoing projects that are designed to understand how the formation and modification of the sub cratonic lithospheric mantle (SCLM) varies across the Kalahari Craton, including the Kaapvaal Craton, the Limpopo Belt and the Zimbabwe Craton. The particular focus of this work is to establish if the Zimbabwean SCLM has the same characteristics as that beneath the Kaapvaal and if not how and why the characteristics vary across the Kalahari Craton.

This work reports a study of peridotite xenoliths taken from the Orapa Mine in Botswana. The eruption of the kimberlite has been dated at $93 \mathrm{Ma}$ (Davis, 1977), suggesting that the Orapa xenoliths may have been subjected to metasomatising fluids during the emplacement of the Bushveld complex (2.05 Ga) and the Karoo igneous event (183 Ma) and related changes in the SCLM. The Orapa mine is located in the Proterozoic Makondi Mobile Belt composed of metasediments and metavolcanics deformed at 2.1 - $1.8 \mathrm{Ga}$ (Griffin et al, 2003.). These rocks are interpreted to be deposited on the passive margins of the Zimbabwe Craton. The mantle xenoliths recovered during this study presumably sample Zimbabwe Craton sub cratonic lithospheric mantle (SCLM).Based on the study of garnets Giffin et al., 2003, proposed that the SCLM underneath Botswana extends to $190 \mathrm{~km}$ depth (Griffin et al, 2003). Magnetotelluric studies are consistent with this interpretation and imply that that the Zimbabwe SCLM underlies this part of the Makondi Mobile Belt (Muller et al, 2009).

Orapa is well known for the presence of eclogite xenoliths but most previous studies have considered peridotites absent or too altered for study. However, following an extensive study of recently drilled kimberlite cores xenoliths at Orapa exceeding $2 \mathrm{~cm}$ in diameter were logged and the compositions of the 129 are estimated as follows: $8 \%$ spinel harzburgites; $8 \%$ garnet harzburgites; $30 \%$ spinel lherzolites; $22 \%$ garnet lherzolites; $14 \%$ dunites; $10 \%$ ecglogites; $<1 \%$ pyroxenites. $8 \%$ of the xenoliths were clearly modified by metasomatism in the form of large amounts of phlogopite and other metasomatic products. These observation are in line with the heavy mineral study of Griffin et al (2003) that reported only $20 \%-30 \%$ of Botswana peridotites are depleted and fertile lherzolites are most common. 12 samples were considered fresh and large enough for more detailed work. The final selection consists of: 3 dunites (of which one is garnet 
bearing), 1 pyroxenite, 2 garnet lherzolites, 2 garnet harzburgites, 2 spinel harzburgites, 2 spinel lherzolites.

\section{PETROGRAPHY}

The samples can be divided into four groups. Group I are the Dunites, group II the garnet bearing lherzolites and harzburgites, group III the spinel lherzolites and harzburgites and group IV the pyroxenite. None of the samples have strong fabrics except for small serpentine veins most likely caused by kimberlite intrusion into cracks. The olivine bearing samples are extensively serpentinized $(20 \%-90 \%$ of olivine is altered) and $5 \%$ of pyroxenes show exsolution of opx into cpx and cpx into spinel. $10 \%$ of the spinels show alteration to mica and the samples contain phlogopite $(<<1 \%$ - 3\%). All garnets have a kelyphyte rim. The pyroxenite contains more than $20 \%$ bluish green amphibole similar to amphiboles reported from the nearby Letlhakane kimberlite pipes by Borst et al (2012). A similar amphibole is also detected in very small amounts in one Group I and one Group III sample. Textures in the samples are equant coarse with the exception of the garnet phenocrysts. Although only trace amounts of clinopyroxene was found in the garnet harzburgite samples, all garnets plot on the 1herzolitic G9 field of Grutter et al., 2004 (Fig 1).

\section{MELT DEPLETION}

After sample preparation, the majority of samples under study proved too small for representative whole rock major element analysis. The analysed samples record $\mathrm{CaO}, \mathrm{Al}_{2} \mathrm{O}_{3}$ and $\mathrm{TiO}_{2}$ depletion typical of mantle residua. Mineral compositions indicate extensive degrees of melt extraction.

Samples from this study have olivine $\mathrm{Mg} \#$ of 91.6 - 93.2 and spinel $\mathrm{Cr} \#$ of $56.4-77.5$. The high $\mathrm{Cr} \#$ of spinels in the spinel facies lherzolites and harzburgites are of comparable composition to those from the Kaapvaal Craton (Fig. 2).

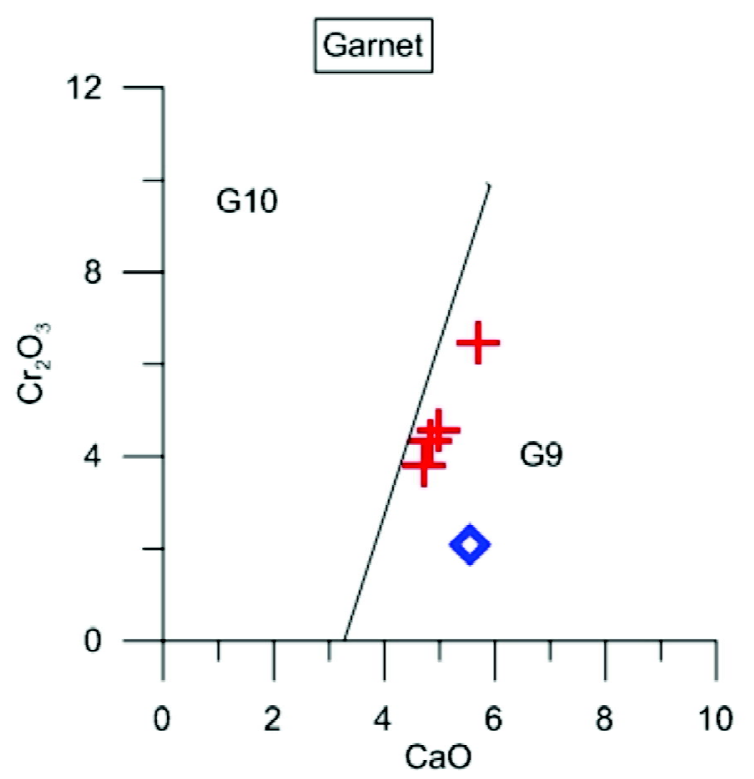

Fig $1 . \mathrm{CaO}$ vs. $\mathrm{Cr}_{2} \mathrm{O}_{3}$ composition of analyzed garnets. Blue diamond is Group I, red crosses are Group II. G9 is the lherzolite field G10 the Harzburgite field taken from Grütter et al., 2004.

Olivine $\mathrm{Mg \#}$ are also comparable to many xenolith suites from cratonic regions and imply 20\% - 40\% melt depletion (Bernstein et al, 2007) similar to Kaapvaal (Simon et al, 2007).

One of the main characteristics and subjects of debate of the Kaapvaal Craton is its silica reenrichment (e.g. Boyd 1989). Initial studies from diamond inclusions, mantle xenoliths and kimberlite concentrates from the Murowa and Sese kimberlites in southern Zimbabwe imply that the SCLM beneath the Zimbabwe Craton has also seen some silica re-enrichment but to a lesser extent than that of the Kaapvaal Craton (Smith et al 2009). In a diagram of modal olivine plotted against olivine Mg\# (Fig. 3), samples from Orapa plot between residua produced by present day melt extraction beneath mid oceanic ridges and the silica-rich xenoliths of Kaapvaal. The limited data sets available to date indicate that the SCLM beneath Botswana is similar to that beneath the Zimbabwe Craton (including data presented at this conference by Borst et al. 2012). 


\section{0 $^{\text {th }}$ International Kimberlite Conference, Bangalore - 2012}

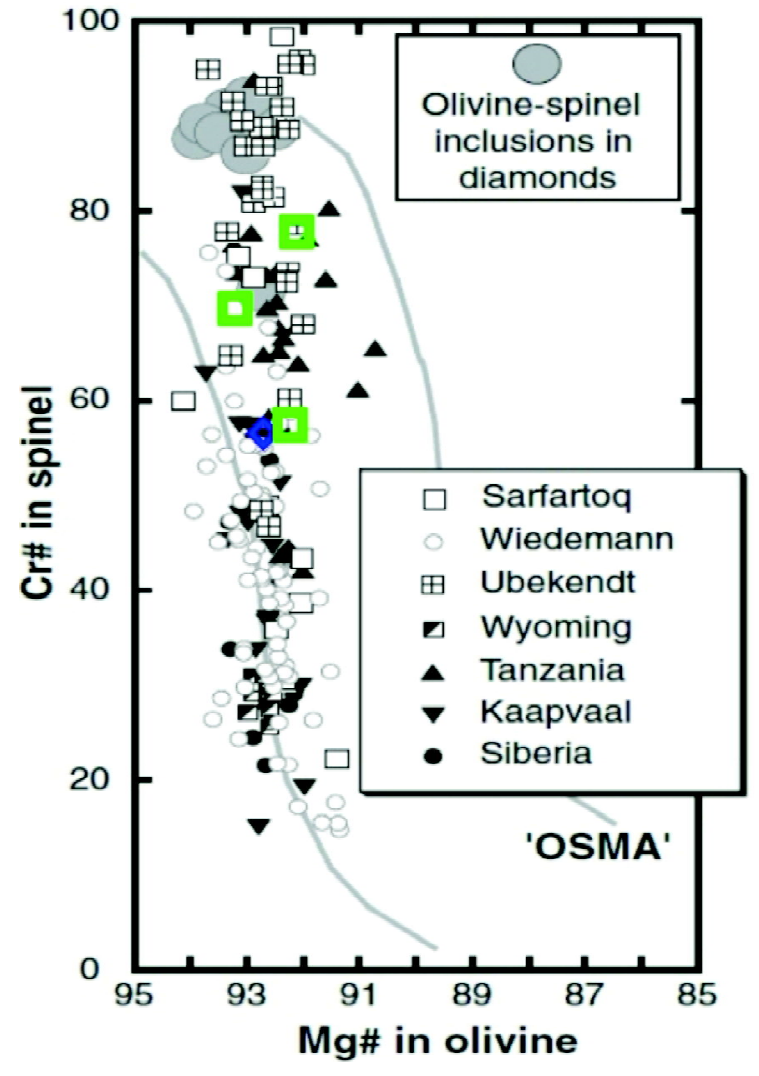

Fig $2 \mathrm{Cr} \#$ in spinel against $\mathrm{Mg \#}$ in coexisting olivine for spinel facies xenolits. Samples of this study (green squares Group III, blue diamond Group I) overlap with highly melt depleted peridotites from different cratons. Other data from Bernstein et al, 2007.

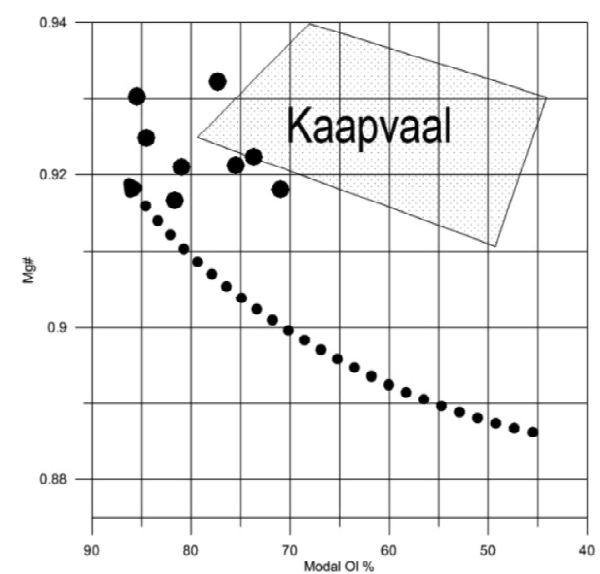

Fig. 3. Mg\# in olivine plotted against modal \% olivine for each sample. Thick black line indicates the oceanic melting trend, gray field represents typical Kaapvaal mantle xenoliths. After Boyd (1989). Samples of this study are plotted.
Thermobarometry performed on three of the garnet bearing samples yielded pressuretemperature between $978^{\circ} \mathrm{C}-4.5 \mathrm{GPa}$ and $1198^{\circ} \mathrm{K}-6.0 \mathrm{GPa}$ with the combined $\mathrm{T}_{\text {Harley }}$ and $\mathrm{P}_{\mathrm{bkn}}$ thermobarometers. These data coincide with a $38-40 \mathrm{~mW}$ geotherm (Fig. 4)

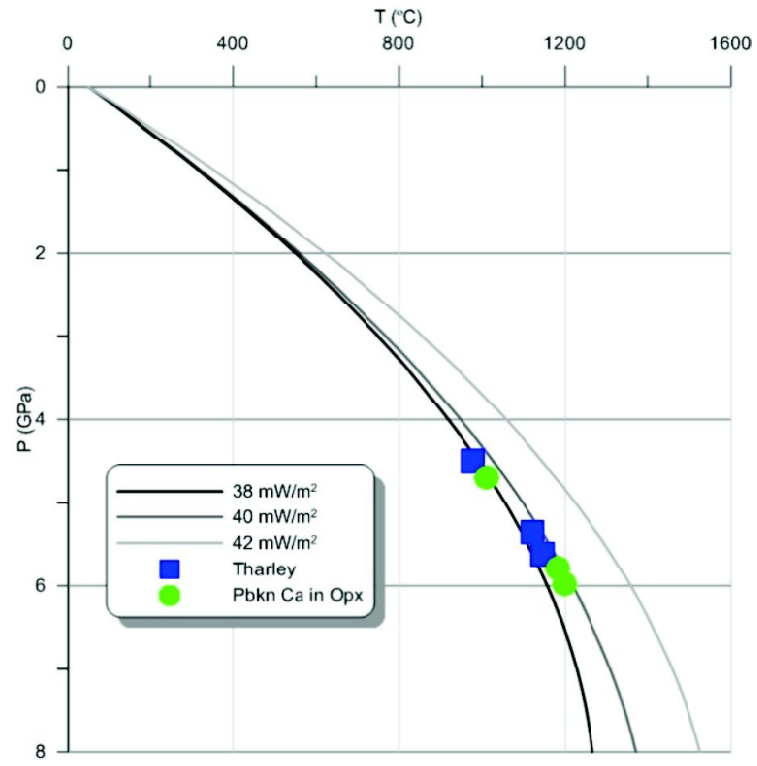

Fig. 4, Pressure temperature calculations with two thermobarometer pairs. Geotherms of 38,40 and $42 \mathrm{~mW} / \mathrm{m}^{2}$ are plotted for comparison.

\section{EQUILIBRATION}

Elemental partitioning between co-existing minerals can be used to assess if equilibrium conditions were achieved. The samples of group I, II and III all have olivine as the major constituent so orthopyroxene and clinopyroxene should be in equilibrium with co-existing olivine. The Mg\#'s of Opx and Cpx should be similar or slightly higher than the Mg\# of olivine in co-existing equilibrium (Pearson et al., 2003). The difference in $\mathrm{Mg} \#$ of Opx and olivine range from 0.6 to 1.1, i.e., minerals are in equilibrium. The difference in $\mathrm{Mg} \#$ of $\mathrm{Cpx}$ and olivine in group II samples range from 0.48 to 0.64 , which also seems to be in equilibrium. Group I samples range from -0.41 to 3.25 and group III from 0.8 to 3.2 . The disequilibrium in group I samples and most of 


\section{0 $^{\text {th }}$ International Kimberlite Conference, Bangalore - 2012}

group III samples suggests late stage formation of $\mathrm{Cpx}$ such that major element equilibrium has not been attained.

\section{FUTURE WORK}

On-going laser ablation ICP-MS studies of the constituent minerals coupled with Nd-Hf isotope mineral data will be used to constrain the major and trace element depletion and enrichment history of the Orapa xenoliths. These data will be compared to results from the nearby Lethlekane mine (Borst et al., this volume, Luguet et al. 2011) and the limited available data from Zimbabwe (Smith et al., 2009) to asses if there is a regional geochemical characteristic of the Zimbabwean SCLM and if that is distinct to that of the Kaapvaal. We will also discuss the processes responsible for the silica re-enrichment and why it differs over the Kalahari Craton.

\section{References}

Bernstein S, Kelemen P B, Hanghøj, 2007, Consistent olivine $\mathrm{Mg \#}$ in cratonic mantle reflects Archean mantle melting to the exhaustion of orthopyroxene, Geology, 35, 459 - 462.

Borst A M, Davidheiser B, Meulemans T J, Davies G $\mathrm{R}, 2012$, The origin and evolution of the lithospheric mantle beneath the Makondi Fold Belt in Botswana; an extensive geochemical study on peridotite xenoliths from the letlhakane diamond mine, This volume.

Boyd F R, 1989, Compositional distinction between oceanic and cratonic lithosphere, Earth and Planetary Science Letters, Vol. 96, 15-26.

Davis, 1977, The ages and uranium contents of zircons from kimberlites and associated rocks. Carnegie Inst. Wash. Yearb., 76 (1977), 631-635.

Griffin W L, O’Reilly S Y, Natapov L M, Ryan C G, 2003, The evolution of the lithospheric mantle beneath the Kalahari Craton and its margins, Lithos, $71,215-241$.

Luguet A, Behrens M, Herwartz D, Pearson D G, 2011, Re-Os and Lu-Hf datin in Letlhakane peridotite xenoliths (Botswana), Goldschmid 2011 abstract.

Muller MR et al., 2009, Lithospheric structure, evolution and diamond prospectivity of the Rehoboth Terrane and western Kaapvaal craton, southern Africa: Constraints from broadband magnetotellurics, Lithos, 112S, 93-105.

Pearson D G, Canil D, Shirey S, 2003, Mantle Samples Included in volcanic Rocks: Xenoliths and Diamonds, Treatise on Geochemistry, Vol. 2, 1-106

Simon N S C, Carlson R W, Pearson D G, Davies G R, 2007, The origin and evolution of the Kaapvaal cratoniclithospheric mantle, Journal of Petrology, Vol. 48, 589-625.

Smith C B, Pearson D G, Bulanova G P, Beard A D, Carlson R W, Wittig N, Sims K, Chimuka L, Muchemwa E, 2009, Extremely depleted lithospheric mantle and diamonds beneath the southern Zimbabwe Craton, Lithos, 112S, 1120 1132 